\title{
The application of PEF technology in food processing and human nutrition
}

\author{
Karolina Nowosad $^{1} \cdot$ Monika Sujka $^{1} \cdot$ Urszula Pankiewicz $^{1} \cdot$ Radosław Kowalski $^{1}$
}

Revised: 23 March 2020/Accepted: 1 May 2020/Published online: 8 May 2020

(C) The Author(s) 2020

\begin{abstract}
During the last decades, many novel techniques of food processing have been developed in response to growing demand for safe and high quality food products. Nowadays, consumers have high expectations regarding the sensory quality, functionality and nutritional value of products. They also attach great importance to the use of environmentally-friendly technologies of food production. The aim of this review is to summarize the applications of PEF in food technology and, potentially, in production of functional food. The examples of process parameters and obtained effects for each application have been presented.
\end{abstract}

Keywords Pulsed electric field · Food processing ·

Functional food

\section{Introduction}

Development of innovative food processing methods can increase the competitiveness of the food industry by improving product quality, introducing new products to the market and reducing production costs (Tiwari et al. 2009). Incorporation of pulsed electric field (PEF) technology into food production was supported by the growing consumer interest in food of high nutritional value, the demand for fresh-like products as well as food produced with the use of environmentally friendly methods (Evans and Cox 2006; Soliva-Fortuny et al. 2009). The studies showed that

Monika Sujka

monika.sujka@up.lublin.pl

1 Department of Analysis and Evaluation of Food Quality, University of Life Sciences in Lublin, Skromna 8, 20-704 Lublin, Poland despite the fact that consumers have rather conservative approach and it is not always easy for them to see the benefits of novel processing technologies, they appreciate the naturalness, improved taste and high nutritional value of the products subjected to PEF (Nielsen et al. 2009; Sonne et al. 2012). As suggested by the results of studies conducted in different countries, providing detailed and reliable information about new technologies may be of key importance for increasing consumer acceptance of products obtained using novel food processing technologies (Lee et al. 2015; Galati et al. 2019; Maherani et al. 2016).

Despite many scientific studies on the principles and applications of PEF technology published so far and the fact that PEF was introduced into the food industry many years ago, this technology is still considered emerging. In the European Union there is no special legislation on food processed with PEF. In general the use of this technique is regulated by the Novel Food Regulation (EU) 2015/2283, but implementation of PEF into production does not automatically mean the food becomes "novel". According to Article 4 of Regulation (EC) No. 258/97, a food product can be considered as novel if the production process applied causes significant changes in its composition or structure influencing nutritional value, metabolism or level of undesirable substances. The studies showed that, for instance, in case of liquid products such as oils, juices and beverages containing juices no significant decreases in content of health-beneficial compounds have been observed as a result of PEF treatment (Guderjan et al. 2005; Zulueta et al. 2007; Salvia-Trujillo et al. 2011; Morales-De La Peña et al. 2012; Vallverdú-Queralt et al. 2012). The party who wants to market the food is responsible for clarifying its regulatory status with the national food authority body. Decision on food novelty is based on the procedures described in the Commission 
Implementing Regulation (EU) 2018/456 and safety assessment must be carried out as a part of the authorisation process. The use of novel processing technologies has the potential to reduce the environmental impact of food production and increase food safety, so their use is regulatory encouraged in the EU (Regulation (EU) 2015/2283). Regulations concerning novel foods exist also in Canada, New Zealand/Australia, China, and Brazil but the definition of "a novel food" may differ (Magnuson et al. 2013). In the United States, prior to 2002, the Food and Drug Administration considered pasteurization as a thermal treatment but in September 2004, the USDA National Advisory Committee on Microbiological Criteria for Foods (NACMCF) redefined the term "pasteurization" as "any process, treatment, or combination thereof, that is applied to food to reduce the most microorganism(s) of public health significance to a level that is not likely to present a public health risk under normal conditions of distribution and storage" allowing methods such as PEF to be used (NACMCF 2004). PEF has been used for the commercial pasteurization of juices in compliance with the mandates of FDA's juice HACCP regulations (21 C.F.R. 120). The juice processors also have to implement sanitation and Good Manufacturing Practices during production of juice and juice products. According to FDA the processes of production should meet a performance standard of $5 \mathrm{log}$ reduction of the most resistant pathogen (FDA 2000).

Pasteurization of liquid foods still remains the main purpose of using PEF technology. The lethal effect of PEF on various vegetative bacteria, mold, and yeast can be strengthen by combining with other physical methods, such as UV radiation (Gachovska et al. 2008), high intensity light pulses (HILP) (Caminiti et al. 2011), ultrasound (Aadil et al. 2018), high pressure carbon dioxide (Pataro et al. 2010) and manothermosonication (Palgan et al. 2012).

\section{General overview: advantages and disadvantages of PEF}

PEF is a method that uses electric waves with high voltage amplitude. Short electrical impulses (from microseconds to milliseconds each) of high voltage (typically $10-80 \mathrm{kV} /$ $\mathrm{cm}$ ) are supplied to the product placed between the electrodes in the chamber (Deeth et al. 2008). Depending on the properties of the processed food product and the effects to be obtained, the process conditions such as electric field strength $(\mathrm{kV} / \mathrm{cm})$, pulse frequency, pulse width, shape of the pulse wave and exposure time (related to the flow rate and volume of fluid in the electrode chamber) can be modified suitably. For instance, the range of electric field strength $0.1-1 \mathrm{kV} / \mathrm{cm}$ causes reversible permeabilization of plant cells, $0.5-3 \mathrm{kV} / \mathrm{cm}$-irreversible permeabilization of plant and animal tissue, $15-40 \mathrm{kV} / \mathrm{cm}$-irreversible permeabilization of microbial cells (Tsong 1996).

In the last decade, one of the main fields of research in the scope of alternative energy-saving processes has been the application of PEF as a non-thermal method in food processing (Soliva-Fortuny et al. 2009). Nevertheless, it should be mentioned that the energy of the electric pulses generates heat due to Joule heating so cooling is necessary to maintain a low temperature of the processed product during PEF treatment. On the other hand, this phenomenon can be applied for a gentle preservation process. The combination of high temperature and PEF membrane electroporation improves also the inactivation efficiency (Jaeger et al. 2010b).

Most of the research on the use of PEF relates to inactivation of enzymes and microorganisms. High voltage impulses break the cell membrane making it permeable to small molecules, which causes the cells to begin to swell and break (Zimmerman 1986). PEF can be used for liquid and semi-solid products e.g. soups, liquid eggs or fruit juices (Qin et al. 1995). Fruit juices processed with this technology were introduced to the US market in 2005 (Ravishankar et al. 2008). In the case of solid products, PEF technology has found application mainly in potato processing industry. Potatoes can be subjected to PEF immediately after peeling and before the cutting step (Faridnia et al. 2015a) or in a form of slices. The effect of PEF is a change in the structural integrity of tissues, which results in more controlled release of intracellular compounds such as reducing sugars or amino acids involved in Maillard reactions, and therefore reduces acrylamide content in cooked or fried potato products (Jaeger et al. 2010a, b; Janositz et al. 2011; Genovese et al. 2019). Potatoes treated with PEF also have a more uniform color and absorb less oil during frying (Ignat et al. 2015; Liu et al. 2018a, b). Another effect of PEF is a softer texture that facilitates potato processing, e.g. cutting (Lebovka et al. 2004) and a significant decrease in drying time of potato discs (Fauster et al. 2018).

Although this technology has been investigated extensively and there are several dozen commercial PEF systems working around the world, the majority of the obtained results refer to the experiments carried out at laboratory scale. The pulsed electric field technology itself is generally considered to be safe for humans, because no dangerous chemical reactions have been detected (Frewer et al. 2011). However, the results of some studies indicate that electrode material constituents (e.g. $\mathrm{Fe}, \mathrm{Cr}, \mathrm{Ni}, \mathrm{Mn}$ ) are released to the liquid food samples due to corrosion (Roodenburg et al. 2005; Pataro et al. 2014). This problem may be overcome by application of carbon electrodes (Toepfl et al. 2004). According to Pataro et al. (2014), 
some electrical parameters such as pulse frequency and the composition of the processed product (e.g. presence of halides) affect the amount of metal released from the electrodes. Undoubtedly, further research is needed to determine the optimal conditions for PEF treatment on an industrial scale, as well as electrode material and geometry, so that undesirable electrode reactions will be eliminated or at least minimized.

A typical PEF unit is composed of a few basic components: high-voltage pulse generator, treatment chamber, fluid-handling system, control and monitoring devices (Fig. 1). The first component supplies the high voltage pulses with required shape, duration and intensity. The generated pulses are applied to a pair of electrodes present in the treatment chamber and the treated product is placed between them. Depending on the type of the treated product (solid, semisolid, liquid, semiliquid), the treatment chambers can be divided into batch treatment chambers and continuous treatment chambers. The latter type is very convenient for industrial processes because allows liquid and semi-liquid products to be pumped through the chamber. The process is controlled by a central computer which is used for setting the parameters, controlling the operation of pump and gathering data from the probes placed inside the chamber (Barbosa-Canovas et al. 2004). In liquid products processed with PEF the serious problem is non-uniformity of electric field distribution inside the treatment chamber caused by its configuration, presence of bubbles/impurities and thermophysical properties of the product itself (Zhang et al. 1995). As a result some parts of the liquid volume can be undertreated (often in central or dead spaces) or overtreated (often in boundary regions). Achieving of electric field uniformity is particularly important in the case of cold pasteurization, because during this process all microorganisms present in the liquid should be exposed to the same electric field strength and the same

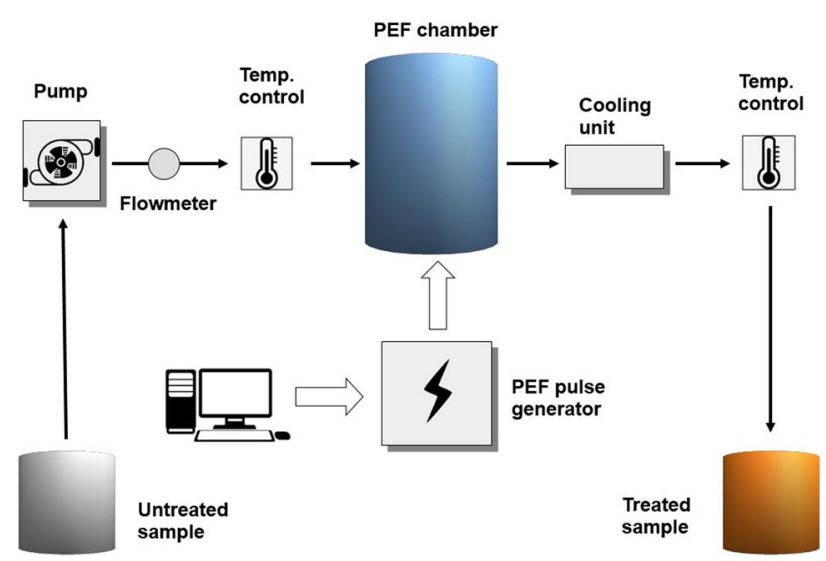

Fig. 1 A typical PEF unit used in food processing number of pulses. To overcome this problem, treatment chambers with parallel plate electrode configurations or multiple PEF treatment chambers placed in series can be used (Buckow et al. 2013).

\section{Mechanism of pulsed electric field}

The application of PEF on plant, animal or microbial cells disturbs transiently or permanently the integrity of cell membrane increasing its permeability, however the mechanism of PEF activity has not been fully understood. Until now, several theoretical models have been suggested, but there is still no evidence of PEF's action regimen at the cellular level (Soliva-Fortuny et al. 2009). Experimental evidence suggests that aqueous hydrophilic pores are formed as a consequence of rearrangements of the membrane components such as water and lipids, induced by long and intense electrical pulses (Weaver 2003). It is not possible to observe directly pores of sizes in nanometers with conventional methods e.g. electron microscopy. However, nowadays computational methods (molecular dynamics simulations) can be used to model the effect of electric field in cell membrane (Leach 2001) The simulations conducted by Tieleman (2004) have evidenced that the electroporation process takes place in two stages: (1) water molecules organized in single wire penetrate the hydrophobic core of the bilayer; (2) the water wires grow in length and expand into water-filled pores, which are later stabilized by reorganization of lipid molecules.

When a biological cell is considered as an electrolyte surrounded by an electrically insulted shell (the cytoplasm surrounded by the plasma membrane) and it is exposed to an external electric field, this results in occurrence of induced transmembrane voltage (Kotnik et al. 2010). Under physiological conditions there is a ionic gradient across the membrane resulting from the work of sodiumpotassium pumps and potassium leak channels. Its value depends on cell type and typically ranges from -80 to - $40 \mathrm{mV}$ (Kotnik and Miklavčič 2006). Permeabilization of cell membrane is a local process and takes place when the transmembrane potential difference induced by electric field reaches $250 \mathrm{mV}$. This part of cell surface becomes highly permeable for small charged molecules such as DNA or metal ions (Teissié and Tsong 1981). Diffusion is observed mainly after the pulse and lasts for seconds and minutes (Gabriel and Teissie 1997). Permeabilization is dependent on field strength, pulse parameters (amplitude, duration, pulse number and repetition rate), membrane composition, surrounding media, temperature, cell size and shape and its orientation to the electric field lines (Valič et al. 2003). This phenomenon can be detected e.g. with the use of fluorescent indicators such as propidium iodide (PI) 
(Sadik et al. 2013) or by means of electrical measurements (bio-impedance or micro-electrodes techniques) (Silve et al. 2011, 2017). The uptake of the indicator by the cells is the evidence of membrane permeabilization. When the operation of the electric field stops, the membrane defects become sealed, and the cells retain the introduced molecules or ions. It depends on the time of exposure and the intensity of the electric field. Resealing can last from a few second to several hours, depending on temperature. For example, at $37^{\circ} \mathrm{C}$ the membrane defects close in a few seconds, at $4{ }^{\circ} \mathrm{C}$ in a few minutes and when cells are maintained on ice-several hours are needed. When the field strength exceeds the critical value significantly, the process is irreversible and can lead to cell destruction (Golzio et al. 2002).

\section{Applications of PEF in food processing}

The PEF technique was of interest already in the twentieth century. At the beginning of the 1990s, a milk pasteurization method was developed in which a low-frequency alternating electric field was used. In 1960 a German engineer Doevenspeck patented a method that used highvoltage electric waves to break down the structure of the cells of food materials (Toepfl et al. 2006). Processing factors such as electric field strength, pulse shape, pulse width, treatment time, pulse frequency and polarity, temperature, treatment in batch or continuous flow system are critical factors determining the efficiency of PEF technology in food processing. Optimization of PEF parameters is required for each specific application of pulsed electric field. Some examples are presented in Table 1.

\section{Drying}

Pre-treatment of the sample with PEF in order to destroy the cell structure reduces its resistance to diffusion and the mass and heat transfer rates between the cells and their surroundings increases (Barba et al. 2015). Research on the impact of initial PEF treatment on drying kinetics as well as changes in color and texture in sliced parsnip and carrot was carried out by Alam et al. (2018). The drying time was reduced to $28 \%$ at $70{ }^{\circ} \mathrm{C}$ and to $21 \%$ at $60{ }^{\circ} \mathrm{C}$ compared to the untreated samples. Wiktor et al. (2016) observed that drying time of the PEF-treated carrot samples was reduced up to $8.2 \%$, the effective water diffusion coefficient increased up to $16.7 \%$, and samples after drying exhibited higher lightness and redness in comparison to the intact tissue. Effect of a PEF pre-treatment on drying of onions was investigated by Ostermeier et al. (2018). The study revealed that a rising electric field strength up to $1.07 \mathrm{kV} /$ $\mathrm{cm}$ caused an increase of the cell disintegration which facilitated the moisture release to the surface of the product. The higher diffusion led to a $30 \%$ reduction in drying time for PEF pre-treated onion samples dried at $45^{\circ} \mathrm{C}$. Telfser and Gómez Galindo (2019) studied the effect of reversible permeabilization as pre-treatment before air drying at $40{ }^{\circ} \mathrm{C}$, vacuum drying and freeze drying of basil (Ocimum basilicum L.) leaves. The application of PEF shortened the drying time by $57 \%$ for air drying, $33 \%$ for vacuum drying and $25 \%$ for freeze drying. Samples which were PEF-treated and vacuum dried were found to be the closest to fresh leaves regarding colour and smell determined by sensory panel. Application of PEF accelerates also the drying of carrots, potatoes, apples, coconuts or paprika (Ade-Omowaye et al. 2001).

\section{Freezing}

Freezing food has one major disadvantage - the formation of ice crystals can destroy the tissue so that after thawing the products (for example soft fruits, leafy vegetables) lose their shape and become sodden. In this form they are not accepted by the consumers. It has been demonstrated that pulsed electric fields can be used to improve freezing tolerance of baby spinach leaves. PEF was applied with vacuum impregnation in the presence of cryoprotectants such as trehalose, sucrose, glucose, and fructose. The combination of these methods caused that leaf cells remained viable and the leaves retained turgor after the freezing and thawing cycle (Demir et al. 2018). Carrot discs treated with PEF after soaking in different cryoprotectant and texturizing agents had higher firmness after thawing than control sample (Shayanfar et al. 2014). Similar studies were carried out for potato strips. The results showed that $\mathrm{PEF}$ treatment by itself (without texturizing and antifreeze agents) was not a suitable pretreatment method but when it was applied with $\mathrm{CaCl}_{2}$ and trehalose potato strips maintained structural integrity, firmness and colour after thawing (Shayanfar et al. 2013). Interestingly, there was no improvement in texture of strawberries frozen and thawed after the application of PEF coupled with vacuum infusion and cryoprotectants. However, such treatment enhanced the color retention of thawed fruits (Velickova et al. 2018).

Application of PEF technology together with freezing or freeze-drying affects freezing time and rate. For example, the study of Jalté et al. (2009) showed that PEF pre-treatment can reduce the freezing time, increase the rate of freeze-drying and improve quality of the freeze-dried potato. Similarly, Wiktor et al. (2015), who studied influence of PEF on freezing and thawing of apple tissue, observed that the total freezing time and the total thawing time were reduced by, respectively, 3.5-17.2\% and $71.5 \%$. Similar results were reported by Ben Ammar et al. (2011) 
Table 1 Examples of process conditions and effects of using PEF in food processing

\begin{tabular}{|c|c|c|c|}
\hline Material & PEF parameters & Effect of PEF & References \\
\hline \multicolumn{4}{|l|}{ Drying } \\
\hline $\begin{array}{l}\text { Basil (Ocimum } \\
\text { basilicum L.) } \\
\text { leaves }\end{array}$ & $\begin{array}{l}65 \text { pulses of } 650 \mathrm{~V} / \mathrm{cm}, 150 \mu \mathrm{s} \text { pulse width, } 760 \mu \mathrm{s} \\
\text { between pulses }\end{array}$ & $\begin{array}{l}\text { Drying times reduced } 57 \% \text { for air drying, } 33 \% \text { for } \\
\text { vacuum drying and } 25 \% \text { for freeze drying }\end{array}$ & $\begin{array}{l}\text { Telfser and } \\
\text { Gómez } \\
\text { Galindo } \\
\text { (2019) }\end{array}$ \\
\hline Parsnip and carrot & $20 \mu \mathrm{s}, 50 \mathrm{~Hz}, 0.9 \mathrm{kV} / \mathrm{cm}$, after 1000 pulses & $\begin{array}{l}\text { Drying time reduced to } 28 \% \text { at } 70{ }^{\circ} \mathrm{C} \text { and to } 21 \% \text { at } \\
60{ }^{\circ} \mathrm{C} \text {, compared to the untreated samples }\end{array}$ & $\begin{array}{l}\text { Alam et al. } \\
\text { (2018) }\end{array}$ \\
\hline Carrot & $\begin{array}{l}\text { Pulse number } 10,50 \text { and } 100 ; 1,85 \text { and } 5 \mathrm{kV} / \mathrm{cm} \text {; } \\
5,63,8 \text { and } 80 \mathrm{~kJ} / \mathrm{kg}\end{array}$ & $\begin{array}{l}\text { Drying time reduced up to } 8.2 \% \text {. Decrease of } \\
\text { sample lightness up to } 25.3 \%\end{array}$ & $\begin{array}{l}\text { Wiktor et al } \\
\text { (2016) }\end{array}$ \\
\hline Potato tissue & $300-400 \mathrm{~V} / \mathrm{cm}$ & $\begin{array}{l}\text { Decreasing the drying temperature approximately } \\
\text { on } 20^{\circ}\end{array}$ & $\begin{array}{l}\text { Lebovka } \\
\text { et al. } \\
\text { (2007) }\end{array}$ \\
\hline \multicolumn{4}{|l|}{ Extraction } \\
\hline $\begin{array}{l}\text { Citrus fruits and } \\
\text { peel (orange, } \\
\text { pomelo and } \\
\text { lemon) }\end{array}$ & $\begin{array}{l}3 \mathrm{kV} / \mathrm{cm} \text { - fruits } \\
10 \mathrm{kV} / \mathrm{cm} \text { - peel }\end{array}$ & $\begin{array}{l}\text { Increased yield of juice by } 25 \% \text { for oranges, } 37 \% \\
\text { for pomelos and } 59 \% \text { for lemon, improved } \\
\text { extraction of polyphenols to } 50 \%\end{array}$ & $\begin{array}{l}\text { El Kantar } \\
\text { et al. } \\
\text { (2018) }\end{array}$ \\
\hline \multirow[t]{3}{*}{$\begin{array}{l}\text { Fruit juice with } \\
\text { the addition of } \\
\text { stevia }\end{array}$} & $30 \mathrm{kV} / \mathrm{cm}$ for $230 \mu \mathrm{s}$ & $\begin{array}{l}\text { The retention of ascorbic acid increased by over } \\
74 \% \text {. The enhancement of anthocyanins and } \\
\text { carotenoids extraction }\end{array}$ & $\begin{array}{l}\text { Carbonell- } \\
\text { Capella } \\
\text { et al. } \\
(2017)\end{array}$ \\
\hline & $40 \mathrm{kV} / \mathrm{cm}$ for $230 \mu \mathrm{s}$ & The highest content of hydroxymethylfurfural & $\begin{array}{l}\text { Carbonell- } \\
\text { Capella } \\
\text { et al. } \\
(2017)\end{array}$ \\
\hline & $21 \mathrm{kV} / \mathrm{cm} 300 \mu \mathrm{s}$ with $2.5 \%$ stevia & $\begin{array}{l}\text { The highest content of bioactive compounds and } \\
\text { sweetening properties obtained with minimal } \\
\text { color changes }\end{array}$ & $\begin{array}{l}\text { Carbonell- } \\
\text { Capella } \\
\text { et al. } \\
(2017)\end{array}$ \\
\hline $\begin{array}{l}\text { Blueberry fruits } \\
\text { (Vaccinium } \\
\text { myrtillus } \text { L.) }\end{array}$ & 1,3 and $5 \mathrm{kV} / \mathrm{cm}, 10 \mathrm{~kJ} / \mathrm{kg}$ & $\begin{array}{l}\text { Increasing the juice yield }(+28 \%) \text { compared to the } \\
\text { untreated sample. The juice obtained had a } \\
\text { significantly higher total phenolic content } \\
(+43 \%) \text {, total anthocyanin content }(+60 \%) \text { and } \\
\text { antioxidant activity }(+31 \%)\end{array}$ & $\begin{array}{l}\text { Bobinaite } \\
\text { et al. } \\
(2015)\end{array}$ \\
\hline \multicolumn{4}{|l|}{ Freezing } \\
\hline $\begin{array}{l}\text { Baby spinach } \\
\text { leaves }\end{array}$ & $\begin{array}{l}\text { Two trains of bipolar, rectangular pulses with } \\
\text { amplitude of } 350 \mathrm{~V} \text {, with } 10 \mathrm{~s} \text { interval between } \\
\text { trains. Each train consisted of } 500 \text { pulses of } 200 \mu \mathrm{s} \\
\text { pulse width and } 1600 \mu \mathrm{s} \text { of space between the } \\
\text { pulses (frequency } 500 \mathrm{~Hz} \text { ) }\end{array}$ & $\begin{array}{l}\text { Improved freezing tolerance by applying vacuum } \\
\text { impregnation and PEF in the presence of } \\
\text { cryoprotectants }\end{array}$ & $\begin{array}{l}\text { Demir et al. } \\
\text { (2018) }\end{array}$ \\
\hline Apple tissue & $\begin{array}{l}800 \mathrm{~V} / \mathrm{cm} \text {, pulse duration } 1000 \mu \mathrm{s} \text {, time interval } \\
100 \mathrm{~ms}, 10 \text { pulses }\end{array}$ & $\begin{array}{l}\text { Acceleration of cooling processes; good } \\
\text { preservation of the macro-shape, inhibition of } \\
\text { shrinking, development of large pores in the } \\
\text { electroporated tissue }\end{array}$ & $\begin{array}{l}\text { Parniakov } \\
\text { et al. } \\
\text { (2016a) }\end{array}$ \\
\hline Beef muscle & $\begin{array}{l}1,4 \mathrm{kV} / \mathrm{cm}, 20 \mu \mathrm{s}, 50 \mathrm{~Hz}, 250 \mathrm{~kJ} / \mathrm{kg} \text { (combined with } \\
\text { freezing and thawing) }\end{array}$ & $\begin{array}{l}\text { Microstructural changes in meat tissue, improved } \\
\text { tenderness and purge loss }\end{array}$ & $\begin{array}{l}\text { Faridnia } \\
\text { et al. } \\
\quad(2015 b)\end{array}$ \\
\hline \multicolumn{4}{|l|}{ Preservation } \\
\hline Fresh berries & $\begin{array}{l}2 \mathrm{kV} / \mathrm{cm} \text {, pulse width } 1 \mu \text { s and } 100 \text { pulses per second } \\
\text { for } 2,4 \text { and } 6 \mathrm{~min}+\text { disinfectant solution }(60 \mathrm{ppm} \\
\text { peracetic acid [PAA]) }\end{array}$ & $\begin{array}{l}\text { The reduction of } E \text {. coli and Listeria innocua } \\
\text { without changing the color and appearance of } \\
\text { blueberries } \\
\text { The softening of the berry structure } \\
\text { Conc. of anthocyanins and phenolic compounds } \\
\text { increased by } 10 \text { and } 25 \% \text {, respectively }\end{array}$ & $\begin{array}{r}\text { Jin et al. } \\
\text { (2017) }\end{array}$ \\
\hline $\begin{array}{l}\text { Peptides isolated } \\
\text { from pine nuts }\end{array}$ & $1800 \mathrm{~Hz}, 15 \mathrm{kV} / \mathrm{cm}$ & No changes of the amino acid sequence & $\begin{array}{l}\text { Lin et al. } \\
\text { (2017) }\end{array}$ \\
\hline
\end{tabular}


Table 1 continued

\begin{tabular}{llll}
\hline Material & PEF parameters & Effect of PEF & References \\
\hline Milk & $\begin{array}{c}25.7 \mathrm{kV} / \mathrm{cm} \text { for } 34 \mu \text { s after heating to } 55^{\circ} \mathrm{C} \text { and } \\
\text { maintained for } 24 \mathrm{~s} \text { and heat treatment at } 63{ }^{\circ} \mathrm{C} \text { for } \\
30 \text { min or at } 73{ }^{\circ} \mathrm{C} \text { for } 15 \mathrm{~min}\end{array}$ & $\begin{array}{c}\text { Inactivation of alkaline phosphatase. Reduced } \\
\text { xanthine (30\%) and plasmin oxidase (7\%) activity }\end{array}$ & $\begin{array}{c}\text { Sharma et al. } \\
(2017)\end{array}$ \\
\hline
\end{tabular}

and Al-Sayed et al. (2018). The authors concluded that electroporation of multicellular tissues led to better connections between intra- and extracellular content allowing increased probability of ice nucleation and faster ice propagation after freezing and correspondingly shortening the freezing time.

\section{Food preservation}

Food deterioration may be caused by several factors such as microorganisms development and activity of endogenous enzymes. The PEF technology, compared to the traditional pasteurization method, not only inactivates pathogenic microorganisms but also enzymes in some extent, minimizes the loss of the original taste, color, texture, nutrients and other thermolabile compounds found in food (Syed et al. 2017). For this reason, it is a promising supplement or substitute for traditional thermal pasteurization. PEF can be successfully used for liquid products with low viscosity and electrical conductivity, e.g. milk and juices.

\section{Microbial inactivation}

Milk and dairy products are processed using various thermal methods to make them safe for human consumption. Incorrect pasteurization of milk causes spoilage of the product and formation of pathogenic bacteria such as Escherichia coli, Listeria spp. and Pseudomonas. The treatment in which high temperatures are used causes nutrient losses (Ercolini et al. 2009). Pulsed electric field not only inactivates bacteria at low temperatures, but also affects minimally the nutritional and sensory properties of the food product. PEF causes inactivation of Gram-negative and Gram-positive bacteria in a whole milk already at $50{ }^{\circ} \mathrm{C}$ (Sharma et al. 2014). Milk that has been thermally preserved can be microbiologically stable for 21 days when stored at $4{ }^{\circ} \mathrm{C}$. However, heat causes unfavorable effects such as: damage to the creaming properties, nonenzymatic browning, degradation of lactose, denaturation of whey proteins (Fox et al. 2015). PEF technology can be used synergistically with heat, antimicrobial agents, membrane filtration and ultraviolet radiation in order to increase the effectiveness of bacterial inactivation and prolonging the period of consumption. In one of the studies of Sharma et al. (2017), milk samples were subjected to PEF with the following parameters: $25.7 \mathrm{kV} / \mathrm{cm}$ for $34 \mu \mathrm{s}$ after heating to $55^{\circ} \mathrm{C}$ and maintained for $24 \mathrm{~s}$ and heat treatment at $63{ }^{\circ} \mathrm{C}$ for $30 \mathrm{~min}$ or at $73{ }^{\circ} \mathrm{C}$ for $15 \mathrm{~min}$. Inactivation of alkaline phosphatase was comparable in all samples. The PEF-treated sample initially exhibited reduced xanthine (30\%) and plasmin oxidase (7\%) activity, however, after 21 days of refrigeration storage, these parameters were similar to the milk sample not processed at all. During storage in all milk samples, lipolytic activity increased and the $\mathrm{pH}$ level dropped. Hemar et al. (2011) reported that PEF has no impact on whey proteins and milk $\mathrm{pH}$, but it can affect the viscosity and particle size when milk is treated with high field strengths.

Jin et al. (2017) studied how PEF affects the native microflora and the population of E. coli Listeria innocua, which have been artificially grafted on blueberries. The combination of PEF and PAA (60 ppm peracetic acid) resulted in the reduction of E. coli and Listeria innocua, but it did not change the color and appearance of blueberries. The only disadvantage of the process was the softening of the berry structure. Anthocyanins and phenolic compounds increased by 10 and 25\%, respectively. Palgan et al. (2012) combined PEF and manothermosonication (MTS) to reduce Listeria innocua in a milk based smoothie. The study showed that the application of MTS followed by PEF was the most effective in inactivating $L$. innocua causing a mean reduction of $5.6 \log \mathrm{cfu} / \mathrm{ml}$.

\section{Spore inactivation}

PEF processing seems to have no effect on endospores although some publications describe a certain level of spore inactivation achieved if the necessary harsh conditions are applied. Spores present a higher resistance to PEF than vegetative cells due to their small sizes, low permeability, dehydration and mineralization (Setlow 1995). Therefore, at present, PEF treatment alone can be applied for pasteurization but not for sterilization purposes. 
However, combined application of PEF with other methods e.g. thermal treatment can lead to successful inactivation of endospores. For instance, Siemer et al. (2014) reported a 3 $\log$ cycles inactivation of $B$. subtilis spores under the following process conditions: electric field strength of $9 \mathrm{kV} /$ $\mathrm{cm}$, inlet temperature of $80{ }^{\circ} \mathrm{C}$, the addition of $10 \%$ sugar to medium. Similarly, Reineke et al.(2015) achieved a 4.67 $\log _{10}$ inactivation of $B$. subtilis spores in saline water when they applied the process conditions: $70{ }^{\circ} \mathrm{C}$ with a flow rate of $5 \mathrm{l} / \mathrm{h}$, a frequency of $150 \mathrm{~Hz}$, an energy input of $226.5 \mathrm{~kJ} / \mathrm{kg}$.

\section{Enzyme inactivation}

Enzymes are less sensitive to the action of PEF than microbes so more intense PEF treatments are required for their inactivation (Ho et al. 1997), but the mechanism of this phenomenon is still not well understood. Probably both electrochemical and thermal effects, which are associated with PEF, cause the changes in the structure and conformation of enzymes leading to their inactivation (Terefe et al. 2013). In the case of grape juice, which is susceptible to the action of many enzymes, PEF did not significantly affect its physicochemical and sensory characteristics but it reduced the activity of polyphenyl oxidase and peroxidase. The duration of PEF action, its intensity and frequency had a significant effect on the relative activity of selected enzymes, which was abolished along with the increase of the above-mentioned parameters (Marselle's-Fontanet and Martin-Belloso 2007).

\section{Extraction of bioactive compounds}

Extraction is one of the most commonly used processes in the industry to obtain valuable compounds and usually it involves chemical and/or thermal treatment of a sample. Numerous studies report that application of pulsed electric field for extraction can enhance its efficiency, reduce the extraction time and minimize any damage to the extracted nutrients. PEF has been used to improve the extraction of intracellular compounds from fruits and vegetables. Luengo et al. (2013) reported that amount of polyphenols extracted from tomatoes and grapes increased after treatment with PEF. The use of this technique enhanced also extraction of polyphenols from borage (Borago officinalis L.) leaves and increases their antioxidant activity. In addition, it also reduced the extraction time, and the increase in pulse intensity was proportional to the amount of polyphenols extracted, as well as to their antioxidant properties (Segovia et al. 2014). Soliva-Fortuny et al. (2017) studied the effect of PEF on the content of phenols, flavonoids and flavan-3-ol as well as on the antioxidant capacity of apples stored at different temperatures (4 and
$22{ }^{\circ} \mathrm{C}$ ) for $48 \mathrm{~h}$. The maximum increase in the total phenol content (13\%) and flavone-3-ol (92\%) was observed in apple treated with the mildest electric field parameters. The antioxidant activity was also higher in apples subjected to PEF (by 43\%) in relation to the untreated samples. Liu et al. (2018a, b) investigated the effect of PEF on the extraction of water-soluble phenolic compounds from onion as well as the antioxidant activity of the extracts. Results indicated that the yield of water-soluble phenolic and flavonoid compounds extracted from onion significantly increased after PEF treatment following water extraction, by 2.2 and 2.7 times, respectively, in comparison to control. The authors noted that the antioxidant activity of extracts increased with the increase in electric field intensity and treatment time. El Kantar et al. (2018) investigated the effect of PEF on citrus fruits (orange, pomelo and lemon). Fruits and peel were treated with a pulsed electric field at a field voltage of $3 \mathrm{kV} / \mathrm{cm}$ and $10 \mathrm{kV} / \mathrm{cm}$, respectively. PEF processing increased the yield of juice by $25 \%$ for oranges, $37 \%$ for pomelos and $59 \%$ for lemon, and improved the extraction of polyphenols to $50 \%$.

PEF is an ideal method used to enhance the extraction process of various intracellular compounds, e.g. sugar from sugar beet (Lopez et al. 2009), phytosterols from maize germs (Guderjan et al. 2005). One of the benefits of using PEF is also obtaining high purity of fruit juices (Lebovka et al. 2003). However, the use of too high intensity can lead to destruction of the cell membrane, cell turgor and may have an adverse effect on the viscosity and elasticity of plant tissue (Lebovka et al. 2004). The ability of PEF to inactivate microorganisms and induce the permeabilization of eukaryotic cells without a significant increase in the temperature of the product can be used in the process of wine production to improve its quality. The low energy consumption and short processing time required to permeabilize grape skin cells are the key advantages of using $\mathrm{PEF}$ in obtaining wines with a high content of phenolic compounds. The high concentration of polyphenols helps in stabilizing the color and improves the quality of the wine during the aging process (Boulton 2001). Phenolic compounds also have pro-health activities (e.g. antioxidant and pro-inflammatory properties). PEF does not affect the change in the taste, color or nutritional value of grape must and wine. It also facilitates the growth of active dry wine yeast that is added to the grape must to provide a faster fermentation process. PEF also reduces the amount of $\mathrm{SO}_{2}$, which spoils the quality of wine (Puertolas et al. 2010).

The fruit juice with the addition of stevia was processed by means of PEF to study the effect of this technology on bioactive compounds and steviol glycosides. PEF treatment resulted in the retention of ascorbic acid by over $74 \%$, the enhancement of anthocyanins and carotenoids extraction. The best results were obtained at $30 \mathrm{kV} / \mathrm{cm}$ for $230 \mu \mathrm{s}$. At 
the highest voltage of $40 \mathrm{kV}$, the highest hydroxymethylfurfural content was found. With PEF carried out at $21 \mathrm{kV} /$ $\mathrm{cm}$ during $300 \mu \mathrm{s}$ with $2.5 \%$ stevia, the highest content of bioactive compounds and sweetening properties was obtained with minimal color changes (Carbonell-Capella et al. 2017).

Lin et al. (2017) investigated the mechanism of improving the antioxidant properties of peptides isolated from pine nuts using PEF. Radical inhibition of DPPH and cellular antioxidant activity (CAA) were used to assess the antioxidant activity of peptides. The structure of electroporated peptides was analyzed by medium-infrared spectrophotometry (MIR) and circular dichroism (CD). The capture of DPPH radicals increased significantly $(89.10 \% \pm 0.20 \%$ to $93.22 \% \pm 0.09 \%)$ under PEF treatment conditions. The pulse frequency was $1800 \mathrm{~Hz}$ and the electric field voltage was $15 \mathrm{kV} / \mathrm{cm}$. PEF did not change the amino acid sequence of Gln-Cys-His-Lys-Pro, GlnCys-His-Gln-Pro, Lys-Cys-His-Gln-Pro.

\section{Starch modification}

Pulsed electric field can be used for modification of potato, corn, wheat, waxy rice, and cassava starches (Han et al. 2009; Hong et al. 2018; Li et al. 2019; Zeng et al. 2016). The researchers observed re-arrangement and destruction of starch molecules as well as a decrease in gelatinization properties, viscosity and crystallinity along with the increase in field strength $(1.25-5 \mathrm{kV} / \mathrm{cm}$ and $30-50 \mathrm{kV} /$ $\mathrm{cm})$. Application of PEF affected starch digestibility increasing level of rapidly digestible starch in potato, wheat and pea starches (PEF intensity of 2.86, 4.29, 5.71, 7.14, and $8.57 \mathrm{kV} / \mathrm{cm}, 600 \mathrm{~Hz}$ of pulse frequency, $6 \mu \mathrm{s}$ of pulse width) (Li et al. 2019) and in waxy rice starch (30, 40 and $50 \mathrm{kV} / \mathrm{cm}$ ) (Zeng et al. 2016). Hong et al. (2018) reported that such starch modification methods like acetylation can be significantly enhanced by PEF treatment (PEF parameters: pulse frequency of $1000 \mathrm{~Hz}$; field intensity of $1.25,2.50,3.75$, and $5.00 \mathrm{kV} / \mathrm{cm}$; pulse duration time of $40 \mu \mathrm{s})$. The use of PEF to support the starch modification methods can enhance the process's efficiency, reduce reaction time and save reagents.

\section{Waste valorisation in the food industry}

Food industry generates huge quantities of by-products and wastes, which are problematic because their disposal is associated with environmental and health related issues. On the other hand, they still can be rich sources of natural bioactive compounds, especially in the fruit and vegetable industry. Recently, much attention has been paid to the use of emerging technologies, including PEF, for the recovery of these compounds. For instance, Ghosh et al.
(2019) proposed combining PEF with mechanical pressing for extraction of functional molecules from the waste chicken breast muscle. Andreou et al. (2020) applied PEF in tomato processing to enhance valorization of tomato waste. They noticed the increase in extraction yield of carotenoid up to $56.4 \%$. Lycopene extraction also increased (from $9.84 \mathrm{mg}$ lycopene/100 g to $14.31 \mathrm{mg} / 100 \mathrm{~g}$ tomato residue) for a PEF treatment at $1.0 \mathrm{kV} / \mathrm{cm}$ for $7.5 \mathrm{~ms}$. The concentration of extracted total phenolic compounds doubled when tomato waste was treated with a $2 \mathrm{kV} / \mathrm{cm}$ and 700 pulses. Other exemplary studies concern the application of PEF for enhancing the extraction of polyphenols from lemon peel residues (Peiró et al. 2019), potato peels (Frontuto et al. 2019), mango and papaya byproducts (Parniakov et al. 2016b).

\section{Impact of PEF on nutrients and bioactive compounds}

Studies published recently have been performed mainly in plant-based products, especially juices. They have shown that PEF treatment can be regarded as safe for such bioactive compounds as vitamins, carothenoids and polyphenols. No significant changes in content of vitamin C were reported for apple juice (200, 300, and 400 pulses, electric field strength $30 \mathrm{kV} / \mathrm{cm}$ ) (Dziadek et al. 2019), pineapple juice (20, 30 and $40 \mathrm{kV}$ and frequency 10, 20, 30 and $40 \mathrm{kHz}$ ) (Indriani et al. 2019) or blueburry juice (350 V) (Zhu et al. 2019). It seems that PEF has no impact on the bioaccessibility of this vitamin (Rodríguez-Roque et al. 2015). Salvia-Trujillo et al. (2011), who studied the effect of PEF processing on content of B vitamins in a beverage containing fruit juices (orange, kiwi, mango, and pineapple) and whole and skim milk, found that niacin and thiamin contents in the fruit beverages were not affected by PEF treatment (electric field strength of $35 \mathrm{kV} / \mathrm{cm}$ for $1800 \mu \mathrm{s}$, a pulse frequency of $200 \mathrm{~Hz}$, and $4 \mu$ s bipolar pulses). The use of PEF for pasteurization has the advantage over heat treatment to preserve bioactive compounds. For example, higher concentrations of phenolic acids and flavonoids were observed in PEF-treated tomato juice and orange juice as compared to the conventional thermally treated samples (Odriozola-Serrano et al. 2008; Agcam et al. 2014). PEF pasteurisation of milk maintains its nutritional value. Studies showed that there was no significant effect of pasteurization in a continuous PEF bench scale system $(35 \mathrm{kV} / \mathrm{cm}$ field strength with 64 pulses of bipolar square wave for $188 \mu \mathrm{s}$ ) on proteins and total solids in milk (Michalac et al. 2003). Similarly, no changes were detected in the retention of thiamine, riboflavin, retinol, cholecalciferol and $\alpha$-tocopherol in skim milk and fresh bovine whole milk subjected to PEF treatment at 
18.3-27.1 kV/cm, $400 \mathrm{~ms}$, at 50-90 ${ }^{\circ} \mathrm{C}$ (Bendicho et al. 2002) or $15-35 \mathrm{kV} / \mathrm{cm}, 12.5-75 \mathrm{~ms}$ at $30^{\circ} \mathrm{C}$ (Riener et al., 2009). However, whole milk treated with PEF (20-35 kV/ $\mathrm{cm}, 24-60 \mathrm{~ms}, 20-40{ }^{\circ} \mathrm{C}$ ) demonstrated a small reduction of the fat content (Bermúdez-Aguirre et al. 2011). More studies are needed to find out how PEF affects milk protein, as the results published so far are inconsistent. No negative effects on the quality and functionality of oils have been shown in the studies concerning the use of PEF $(1.8 \mathrm{kV} /$ $\mathrm{cm}, 1.6 \mathrm{~kJ} / \mathrm{kg}$ ) for enhancing oil extraction form olives (Andreou et al. 2017). In the case of meat and fish products the number of studies is still too small to draw far-reaching conclusions on the impact of PEF on their nutritional value.

\section{The potential use of PEF in production of food with increased nutritional value}

Pulsed electric fields has been be applied for enrichment of microorganisms in ions essential for proper functioning of human organism (Table 2). Cell biomass prepared in this way may potentially be used for production of functional food. Yeasts are known for their ability to accumulate metal ions from aqueous solutions, e.g. by adsorption and absorption or metabolism (Cha and Cho 2009). Bioaccumulation of metal ions by Saccharomyces cerevisiae strains takes place in two stages. In the first stage, biosorption or "passive capture" takes place. It is independent of yeast metabolism and associated with the accumulation of cations on the outer surface of the cell wall. The metal ions are then adsorbed to the anionic sites. The second stage called bioaccumulation or "active capture" is already dependent on the cell metabolism and involves the penetration of metal ions into the cell by means of specific membrane transporters. Metal ions accumulate in vacuoles (MacDiarmid et al. 2002). This mechanism of cation binding may lead to the formation of organic linkages called "bioplexes". It has been shown that protein and mineral complexes (metaloproteins or bioplexes) are very well assimilated by human organism (De Nicola et al. 2007). The use of yeast or bacteria as a carrier of bioplexes can help to enrich diets with deficient elements such as magnesium, zinc, calcium or selenium. The studies of Pankiewicz and Jamroz (2013), Pankiewicz et al. (2014) showed that yeast cells treated with PEF can accumulate magnesium, zinc and calcium more efficiently due to the phenomenon of electroporation. The authors reported that bioaccumulation of magnesium was 1.5 times higher, zinc-two times higher and calcium even 6 times higher when compared to the culture not treated with PEF. Observations of the PEF-treated yeast cells using laser confocal microscopy revealed that zinc ions are dispersed mainly in cell organelles, and magnesium ions-in the cell wall (Pankiewicz et al. 2015).

Application of PEF can also enhance bioaccumulation of magnesium ions in Lactobacillus rhamnosus B 442, Lactobacillus rhamnosus 1937 and Lactococcus lactis JBB 500 cells, which can then be used for production of ice cream. The addition of bacteria enriched with $\mathrm{Mg}^{2+}$ did not affect the physicochemical characteristics (freezing, fusibility, hardness) of the ice cream and did not change the color of the samples. The higher total number of microorganisms was noted in the ice cream than in the starter cultures, however, the viability of these bacteria was lower than in the control samples (Góral et al. 2018). Góral et al. (2019a, b) used PEF for enhancing bioaccumulation of calcium and zinc in the cells of Lactobacillus rhamnosus B 442. The highest bioaccumulation of zinc was observed when the following PEF parameters were applied: field strength $3 \mathrm{kV} / \mathrm{cm}$, pulse width $20 \mu \mathrm{s}$ and electroporation time of $20 \mathrm{~min}$. The optimal PEF parameters for calcium accumulation were as follows: field strength $3.0 \mathrm{kV} / \mathrm{cm}$, exposure time $10 \mathrm{~min}$, and pulse width $75 \mu \mathrm{s}$. Bioaccumulation of $\mathrm{Zn}^{2+}$ and $\mathrm{Ca}^{2+}$ was higher than in the control sample (with the addition of zinc and without PEF treatment) by, respectively, $164 \%$ and $300 \%$. Lactobacillus rhamnosus B 442 cells enriched with zinc ions were used for the production of two types of ice cream: unfermented and fermented (Pankiewicz et al. 2019). Also in the case of $\mathrm{Se}^{2+}$, the application of pulsed electric fields improves accumulation of this element in yeast cells up to $68 \%$ (Pankiewicz et al. 2017).

Results of some studies indicate that the use of PEF during juice production may result in higher content of vitamins and polyphenolic compounds compared to those obtained by traditional technology. Odriozola-Serrano et al. (2008) used PEF (electric field strength of $35 \mathrm{kV} / \mathrm{cm}$, field frequency in the range of $50-250 \mathrm{~Hz}$ and pulse width from 1 to $7 \mu$ s) to obtain strawberry juice with a higher nutritional value in terms of vitamin $\mathrm{C}$, anthocyanins and antioxidants contents. They observed $98 \%$ retention of vitamin C, from 83 to $102 \%$ retention of anthocyanins, whereas retention of the antioxidants ranged from 75 to $100 \%$. Maximum retention was obtained when bipolar impulses were applied at field strength of $35 \mathrm{kV} / \mathrm{cm}$, pulse width of $1 \mu$ s and frequency of $250 \mathrm{~Hz}$. Cortés et al. (2006) noticed that content of vitamin $\mathrm{A}$ in orange juice treated with PEF was higher by $8.1 \%$ than in the pasteurized juice. Salvia-Trujillo et al. (2011) showed that beverages containing milk and fruit juice (kiwi, mangoes, oranges and pineapples) treated with high intensity PEF had higher vitamin B2 content than those which were treated thermally. Agcam et al. (2014) in comparative studies of orange juice treated with PEF and thermal pasteurization found that flavonoids and phenolic acids in PEF-treated 
Table 2 An overview of studies on the application of PEF for increasing biosorption of the selected elements by microorganisms

\begin{tabular}{|c|c|c|c|c|}
\hline Microorganism & Nutrient & Conditions of PEF treatment & Effects & References \\
\hline $\begin{array}{l}\text { Saccharomyces } \\
\text { cerevisiae }\end{array}$ & Magnesium ions & $\begin{array}{l}\text { 15-min exposure of the } 20 \text {-h grown } \\
\text { culture to PEF of the } 2000 \mathrm{~V} \text { and } \\
\text { pulse width } 20 \mu \mathrm{s} ; \text { magnesium } \\
\text { concentration of } 100 \mu \mathrm{g} / \mathrm{mL}\end{array}$ & $\begin{array}{l}\text { Accumulation of magnesium in the } \\
\text { yeast biomass reached maximum } \\
3.98 \mathrm{mg} / \mathrm{g} \mathrm{dm}\end{array}$ & $\begin{array}{l}\text { Pankiewicz } \\
\text { and.Jamroz } \\
(2010)\end{array}$ \\
\hline $\begin{array}{l}\text { Saccharomyces } \\
\text { cerevisiae }\end{array}$ & Zinc ions & $\begin{array}{l}15 \text { min exposure of the } 20 \mathrm{~h} \text { grown } \\
\text { culture to PEFs of } 1500 \mathrm{~V} \text { and } \\
10 \mu \text { s pulse width; } 100 \mu \mathrm{g} \mathrm{Zn} / \mathrm{mL} \\
\text { medium }\end{array}$ & $\begin{array}{l}\text { Accumulation of zinc in the yeast } \\
\text { biomass reached a maximum of } \\
15.57 \mathrm{mg} / \mathrm{g} \text { d.m ( } 63 \% \text { higher than in } \\
\text { the control) }\end{array}$ & $\begin{array}{l}\text { Pankiewicz } \\
\text { and Jamroz } \\
\text { (2011) }\end{array}$ \\
\hline $\begin{array}{l}\text { Saccharomyces } \\
\text { cerevisiae }\end{array}$ & Calcium ions & $\begin{array}{l}20 \text { min exposure of the } 20 \mathrm{~h} \text { grown } \\
\text { culture to PEF of the } 5.0 \mathrm{kV} / \mathrm{cm} \text { and } \\
20 \mu \text { s pulse width; calcium } \\
\text { concentration } 100 \mu \mathrm{g} / \mathrm{mL} \text { medium }\end{array}$ & $\begin{array}{l}\text { Bioaccumulation of calcium in the } \\
\text { yeast biomass reached maximum } \\
2.98 \mathrm{mg} / \mathrm{g} \mathrm{d} . \mathrm{m} \text {. It constituted } 30 \% \\
\text { of the total calcium in the medium }\end{array}$ & $\begin{array}{l}\text { Pankiewicz } \\
\text { and Jamroz } \\
(2013)\end{array}$ \\
\hline $\begin{array}{l}\text { Saccharomyces } \\
\text { cerevisiae }\end{array}$ & $\begin{array}{l}\text { Magnesium and } \\
\text { zinc ions }\end{array}$ & $\begin{array}{l}15 \text { min exposure time, culture grown } \\
\text { for } 20 \mathrm{~h} \text { field strength of } 5.0 \mathrm{kV} / \mathrm{cm} \text {, } \\
\text { pulse width of } 20 \mu \mathrm{s} \text {; concentration } \\
\text { of } 100 \mu \mathrm{g} \mathrm{Mg}^{2+} / \mathrm{mL} \text { and } 150 \mu \mathrm{g} \\
\mathrm{Zn}^{2+} / \mathrm{mL} \mathrm{medium}\end{array}$ & $\begin{array}{l}\text { Bioccumulation of magnesium and } \\
\text { zinc reached maximum levels of } \\
2.85 \text { and } 11.41 \mathrm{mg} / \mathrm{g} \text { d.m., } \\
\text { respectively. Optimization of ion } \\
\text { pair concentration and PEF } \\
\text { parameters caused a } 1.5 \text { or twofold } \\
\text { increase of } \mathrm{Mg} \text { and } \mathrm{Zn} \\
\text { accumulation, respectively }\end{array}$ & $\begin{array}{l}\text { Pankiewicz } \\
\text { et al. (2014) }\end{array}$ \\
\hline $\begin{array}{l}\text { Saccharomyces } \\
\text { cerevisiae }\end{array}$ & $\begin{array}{l}\text { Selenium and zinc } \\
\text { ions } \\
\text { (simultaneously) }\end{array}$ & $\begin{array}{l}\text { Electric field strength of } 3 \mathrm{kV} / \mathrm{cm} \text { and } \\
\text { pulse width of } 10 \mu \mathrm{s} \text {, treatment of } \\
20 \text {-h culture for } 10 \mathrm{~min} \text {; ion con. } \\
-100 \mu \mathrm{g} \mathrm{Se} / \mathrm{mL} \text { and } 150 \mu \mathrm{g} \mathrm{Zn} / \\
\mathrm{mL} \text { medium }\end{array}$ & $\begin{array}{l}\text { Increase of ions accumulation by } 65 \% \\
\text { for selenium }(43.07 \mathrm{mg} / \mathrm{g} \mathrm{d} \text { d.m.) and } \\
100 \% \text { for zinc }(14.48 \mathrm{mg} / \mathrm{g} \mathrm{d.m.})\end{array}$ & $\begin{array}{l}\text { Pankiewicz } \\
\text { et al. (2017) }\end{array}$ \\
\hline $\begin{array}{l}\text { Lactobacillus rhamnosus } \\
\text { B } 442\end{array}$ & Magnesium ions & $\begin{array}{l}5 \text { min exposure of the } 20 \mathrm{~h} \text { grown } \\
\text { culture to PEF of the } 2.0 \mathrm{kV} / \mathrm{cm} \text { and } \\
20 \mu \mathrm{s} \text { pulse width at conc. } \\
400 \mu \mathrm{gg} \mathrm{m}^{2+} / \mathrm{mL} \text { medium }\end{array}$ & $\begin{array}{l}\text { PEF caused an increase of magnesium } \\
\text { concentration in the cells by } 220 \% \\
\text { in comparison to the control not } \\
\text { treated with PEF, accumulation of } \\
\text { magnesium in the biomass reached } \\
\text { maximum } 4.28 \mathrm{mg} / \mathrm{g} \text { d.m. }\end{array}$ & $\begin{array}{l}\text { Góral, } \\
\text { Pankiewicz } \\
\text { (2017) }\end{array}$ \\
\hline $\begin{array}{l}\text { Lactobacillus rhamnosus } \\
\text { B 442, Lactobacillus } \\
\text { rhamnosus } 1937 \text {, and } \\
\text { Lactococcus lactis JBB } \\
500\end{array}$ & Magnesium ions & $\begin{array}{l}5 \text { min at pulse width } 20 \mu \mathrm{s} \text {, electric } \\
\text { field strength } 2.0 \mathrm{kV} / \mathrm{cm} \text {, at the field } \\
\text { frequency of } 1 \mathrm{~Hz} \text {; ion conc. of } \\
400 \mu \mathrm{g} \mathrm{Mg}^{2+} / \mathrm{mL} \text { medium }\end{array}$ & 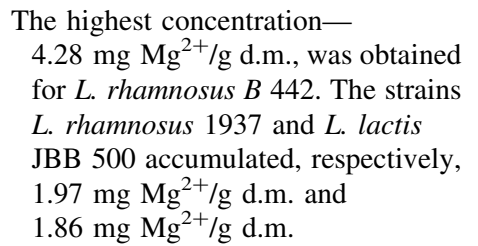 & $\begin{array}{l}\text { Góral et al. } \\
(2018)\end{array}$ \\
\hline $\begin{array}{l}\text { Lactobacillus rhamnosus } \\
\text { B } 442\end{array}$ & Zinc ions & $\begin{array}{l}\text { Field strength of } 3.0 \mathrm{kV} / \mathrm{cm} \text {, pulse } \\
\text { width of } 20 \mu \mathrm{s} \text {, electroporation time } \\
\text { of } 15 \mathrm{~min} \text { after } 20 \mathrm{~h} \text { of culturing } \\
\text { and at zinc conc. of } 500 \mu \mathrm{g} / \mathrm{mL} \\
\text { medium }\end{array}$ & $\begin{array}{l}\text { Bioaccumulation of zinc increased by } \\
164 \% \text { compared to the control (no } \\
\text { PEF). The maximum content of zinc } \\
\text { ions from cells was } 2.85 \mathrm{mg} \mathrm{Zn} \mathrm{Zn}^{2+} / \mathrm{g} \\
\text { d.m. PEF did not reduce bacterial } \\
\text { viability or biomass }\end{array}$ & $\begin{array}{l}\text { Góral et al. } \\
(2019 a, b)\end{array}$ \\
\hline
\end{tabular}

one were more stable than in juice treated with the thermal pasteurization. PEF also allows the preservation of the initial content of fatty acids and amino acids in the product. Zulueta et al. (2007) did not notice a decrease in the content of saturated, monounsaturated or polyunsaturated fatty acids in orange juice-milk beverage fortified with $n-3$ fatty acids and oleic acid processed by high-pulsed electric field. Morales-De La Peña et al. (2012) noted that the content of free amino acids in a fruit juice-soy milk beverage treated with high intensity pulsed electric field and stored at $4{ }^{\circ} \mathrm{C}$ was higher than in the beverages thermally treated. On the other hand, the content of histidine, tyrosine, methionine and leucine was lower in the beverages subjected to thermal pasteurization.

PEF can also be used to support the formation of an iron-glycine complex which is stable and has good bioavailability. Zhang et al. (2017) obtained the highest yield of the Fe-glycine complex $(81.2 \%)$ and the highest iron chelation capacity $(107.13 \mathrm{mg} / \mathrm{L})$, using PEF with an electric field strength of $4 \mathrm{kV} / \mathrm{cm}$, frequency of $1 \mathrm{kHz}$ and 
pulse width of $40 \mu$ s for $15 \mathrm{~min}$. The yield value obtained was higher than in the case of the complex formed by thermal treatment $\left(30 \mathrm{~min}, 60{ }^{\circ} \mathrm{C}\right)$. Based on the results obtained, the authors concluded that PEF can be used in industry to form metal ion complexes with protein amino acids.

Pharmacological effects (e.g. anti-inflammatory, anticancer, antioxidant) of C-phycocyanin (C-PC) derived from Spirulina platensis, caused this compound to have potential applications in the production of functional foods (Liu et al. 2016). Phycocyanin is a pigment-protein complex with a blue color, which is widely used as a natural food color in the food industry (Taufiqurrahmi et al. 2017). Martinez et al. (2017) used PEF to enhance extraction of C-phycocyanin from A. platensis. The purity of the extract obtained from PEF-treated cells was much higher than in the case of other techniques that consisted of complete destruction of the cell.

The development of technology allows the introduction of "novel food" to trade. An example of such food are proteins obtained from microalgae Ulva sp. Protein extraction from these microorganisms is possible due to the use of chemical substances, however this method has serious consequences, therefore PEF combined with osmotic shock and mechanical press was used as an alternative extraction method. Subsequently, the extracted proteins were identified and a specific allergen was assigned to them. Extracts that were obtained with PEF contained only one food allergen-superoxide dismutase (SOD), however, more research is needed on the allergenicity of proteins extracted from macroalgae to assess the risk for human consumption (Polokovsky et al. 2019).

\section{Conclusion}

The present review discussed the selected current and potential applications of PEF in food industry. Development of new technologies in food processing is forced, among others, by the growing interest of consumers in fresh-like products of high nutritional value, and the demand for food produced with the use of environmentally friendly methods. PEF is a method that uses electric waves with high voltage amplitude. Short electrical impulses (from microseconds to milliseconds each) of high voltage (typically $10-80 \mathrm{kV} / \mathrm{cm}$ ) are supplied to the product placed between the electrodes in the chamber. This technology can be used alone or in combination with other methods to obtain products in more energy efficient (e.g. by lowering temperature and time of extraction) and environmentally friendly way. PEF can be applied for pasteurization, enhancement of such processes as drying, freezing, or extraction, but can also support development of functional food containing e.g. easily absorbed ions of elements essential for proper functioning of the human body.

Research of pulsed electric fields technology is carried out around the world. Although this technology has been investigated extensively and there already are commercial PEF systems working in different countries, the majority of the obtained results still refer to the experiments carried out at laboratory scale.

\section{Compliance with ethical standards}

Conflict of interest The authors declare that they have no conflict of interest.

Open Access This article is licensed under a Creative Commons Attribution 4.0 International License, which permits use, sharing, adaptation, distribution and reproduction in any medium or format, as long as you give appropriate credit to the original author(s) and the source, provide a link to the Creative Commons licence, and indicate if changes were made. The images or other third party material in this article are included in the article's Creative Commons licence, unless indicated otherwise in a credit line to the material. If material is not included in the article's Creative Commons licence and your intended use is not permitted by statutory regulation or exceeds the permitted use, you will need to obtain permission directly from the copyright holder. To view a copy of this licence, visit http://creativecommons. org/licenses/by/4.0/.

\section{References}

Aadil RM, Zeng X-A, Han Z et al (2018) Combined effects of pulsed electric field and ultrasound on bioactive compounds and microbial quality of grapefruit juice. J Food Process Preserv 42:e13507

Ade-Omowaye BIO, Angersbach A, Taiwoy KA, Knorr D (2001) Use of pulsed electric field pretreatment to improve dehydration characteristics of plant based foods. Trends Food Sci Technol 12:285-295

Agcam E, Akyildiz A, Evrendilek GA (2014) Comparison of phenolic compounds of orange juice processed by pulsed electric fields (PEF) and conventional thermal pasteurisation. Food Chem 143:354-361

Alam M, Lyng J, Frontuto D, Marra F, Cinquanta L (2018) Effect of pulsed electric field pretreatment on drying kinetics, color, and texture of parsnip and carrot. J Food Sci 83:2159-2166

Al-Sayed L, Boy V, Madieta E, Mehinagic E, Lanoisellé J-L (2018) Pulsed electric fields (PEF) as pre-treatment for freeze-drying of plant tissues. In: IDS'2018-21st international drying symposium València, Spain, 11-14 September 2018

Andreou V, Dimopoulos G, Alexandrakis Z, Katsaros G, Oikonomou D, Toepfl S, Heinz V, Taoukis P (2017) Shelf-life evaluation of virgin olive oil extracted from olives subjected to nonthermal pretreatments for yield increase. Innov Food Sci Emerg Technol 40:52-57

Andreou V, Dimopoulos G, Dermesonlouoglou E, Taoukis P (2020) Application of pulsed electric fields to improve product yield and waste valorization in industrial tomato processing. J Food Eng 270:109778

Barba FJ, Parniakov O, Pereira SA, Wiktor A, Grimi N, Boussetta N, Saraiva JA, Rasoe J, Martin-Belloso O, Witrowa-Rajchert D, Lebovka N, Vorobiev E (2015) Current applications and new 
opportunities for the use of pulsed electric fields in food science and industry. Food Res Int 77:773-798

Barbosa-Canovas G, Tapia MS, Cano MP (2004) Novel food processing technologies. CRC Press, New York

Ben Ammar J, Van Hecke E, Lebovka N, Vorobiev E, Lanoisellé JL (2011) Freezing and freeze-drying of vegetables: benefits of a pulsed electric fields pre-treatment. in: CIGR section VI international symposium on towards a sustainable food chain food process, bioprocessing and food quality management. Nantes, France-April 18-20, 2011

Bendicho S, Espachs A, Arántegui J, Martin O (2002) Effect of high intensity pulsed electric fields and heat treatments on vitamins of milk. J Dairy Res 69:113-123

Bermúdez-Aguirre D, Fernández S, Esquivel H, Dunne PC, BarbosaCánovas GV (2011) Milk processed by pulsed electric fields: evaluation of microbial quality, physicochemical characteristics, and selected nutrients at different storage conditions. J Food Sci 76:S289-S299

Bobinaite R, Pataro G, Lamanauskas N, Šatkauskas S, Viškelis P, Ferrari G (2015) Application of pulsed electric field in the production of juice and extraction of bioactive compounds from blueberry fruits and their by-products. J Food Sci Technol 52(9):5898-5905

Boulton RB (2001) The copigmentation of anthocyanins and its role in the colour of red wine: a critical review. Am J Enol Vitic 55:67-87

Buckow R, Ng S, Toepfl S (2013) Pulsed electric field processing of orange juice: a review on microbial, enzymatic, nutritional, and sensory quality and stability. Compr Rev Food Sci Food Saf 12:455-467

Caminiti IM, Palgan I, Noci F, Muñoz A, Whyte P, Cronin DA, Morgan DJ, Lyng JG (2011) The effect of pulsed electric fields (PEF) in combination with high intensity light pulses (HILP) on Escherichia coli inactivation and quality attributes in apple juice. Innov Food Sci Emerg Technol 12:118-123

Carbonell-Capella J, Buniowska M, Cortes C, Zulueta Frigola A, Esteve M (2017) Influence of pulsed electric field processing on the quality of fruit juice beverages sweetened with Stevia rebaudiana. Food Bioprod Process 101:214-222

Cha J, Cho Y (2009) Determination of optimal conditions for zinc hyperaccumulation by Saccharomyces cerevisiae FF-10. J Korean Soc App Biol Chem 52:227-233

Commission Implementing Regulation (EU) 2018/456 of 19 March 2018 on the procedural steps of the consultation process for determination of novel food status in accordance with Regulation (EU) 2015/2283 of the European Parliament and of the Council on novel foods

Cortés C, Torregrosa F, Esteve MJ, Frígola A (2006) Carotenoid profile modification during refrigerated storage in untreated and pasteurized orange juice and orange juice treated with highintensity pulsed electric fields. J Agric Food Chem 54:6247-6254

De Nicola R, Hazelwood L, De Hulster E, Walsh M, Knijnenburg T, Reinders M (2007) Physiological and transcriptional responses of Saccharomyces cerevisiae to zinc limitation in chemostat cultures. App Environ Microbiol 73:7680-7692

Deeth HC, Datta N, Ross AIV, Dam XT (2008) Pulsed electric field technology: effect on milk and fruit juices. In: Tewari Gaurav, Juneja VK (eds) Advances in thermal and non thermal food preservation. Wiley-Blackwell, Hoboken

Demir E, Dymek K, Galindo GF (2018) Technology allowing baby spinach leaves to acquire freezing tolerance. Food Bioprocess Technol 11:809-817

Dziadek K, Kopeć A, Dróżdż T, Kiełbasa P, Ostafin N, Bulski K, Oziembłowski M (2019) Effect of pulsed electric field treatment on shelf life and nutritional value of apple juice. J Food Sci Technol 56:1184-1191

El Kantar S, Boussetta N, Lebovka N, Foucart F, Rajha H, Maroun H, Louka N, Vorobiev E (2018) Pulsed electric field treatment of citrus fruits: improvement of juice and polyphenols extraction. Innov Food Sci Emerg Technol 46:153-161

Ercolini D, Russo F, Ferrocino I, Villani F (2009) Molecular identification of mesophilic and psychrotrophic bacteria from raw cow's milk. Food Microbiol 26(2):228-231

Evans G, Cox DN (2006) Australian consumers' antecedents of attitudes towards foods produced by novel technologies. Br Food J 108:916-930

Faridnia F, Burritt DJ, Bremer PJ, Oey I (2015a) Innovative approach to determine the effect of pulsed electric fields on the microstructure of whole potato tubers: use of cell viability, microscopic images and ionic leakage measurements. Food Res Int 77:556-564

Faridnia F, Ma QL, Bremer PJ, Burritt DJ, Hamid N, Oey I (2015b) Effect of freezing as pre-treatment prior to pulsed electric field processing on quality traits of beef muscles. Innov Food Sci Emerg Technol 29:31-40

Fauster T, Schlossnikl D, Rath F, Ostermeier R, Teufel F, Toepfl S, Jaeger H (2018) Impact of pulsed electric field (PEF) pretreatment on process performance of industrial French fries production. J Food Eng 235:16-22

FDA (2000) 21 CFR Par 179: irradiation in the production, processing and handling of food. Fed Regist 65:71056-71058

Fox PF, Uniacke-Lowe T, McSweeney PLH, O’Mahony JA (2015) Dairy chemistry and biochemistry. Springer, Basel

Frewer L, Bergmann K, Brennan M, Lion R, Meertens R, Rowe G, Siegrist M, Vereijken C (2011) Consumer response to novel agri-food technologies: implications for predicting consumer acceptance of emerging food technologies. Trends Food Sci Technol 22:442-456

Frontuto D, Carullo D, Harrison SM et al (2019) Optimization of pulsed electric fields-assisted extraction of polyphenols from potato peels using response surface methodology. Food Bioprocess Technol 12:1708-1720

Gabriel B, Teissie J (1997) Direct observation in the millisecond time range of fluorescent molecule asymmetrical interaction with the electropermeabilized cell membrane. Biophys J 73(5):2630-2637

Gachovska T, Kumar S, Thippareddi H, Subbiah J, Williams F (2008) Ultraviolet and pulsed electric field treatments have additive effect on inactivation of $E$. coli in apple juice. J Food Sci 73:M412-M417

Galati A, Tulone A, Moavero P, Crescimanno M (2019) Consumer interest in information regarding novel food technologies in Italy: the case of irradiated foods. Food Res Int 119:291-296

Genovese J, Tappi S, Luo W, Tylewicz U, Marzocchi S, Marziali S, Romani S, Ragni L, Rocculi P (2019) Important factors to consider for acrylamide mitigation in potato crisps using pulsed electric fields. Innov Food Sci Emerg Technol 55:18-26

Ghosh S, Gillis A, Sheviryov J, Levkov K, Golberg A (2019) Towards waste meat biorefinery: extraction of proteins from waste chicken meat with non-thermal pulsed electric fields and mechanical pressing. J Clean Prod 208:220-231

Golzio MJ, Teissié J, Rols MP (2002) Direct visualization at the single-cell level of electrically mediated gene delivery. Proc Natl Acad Sci USA 99:1292-1297

Góral M, Pankiewicz U (2017) Effect of pulsed electric fields (PEF) on accumulation of magnesium in Lactobacillus rhamnosus B 442 cells. J Membrane Biol 250:565-572

Góral M, Kozłowicz K, Pankiewicz U, Góral D (2018) Magnesium enriched lactic acid bacteria as a carrier for probiotic ice cream production. Food Chem 239:1151-1159 
Góral M, Pankiewicz U, Sujka M, Kowalski R (2019a) Bioaccumulation of zinc ions in Lactobacillus rhamnosus B 442 cells under treatment of the culture with pulsed electric field. Eur Food ResTechnol 245:817-824

Góral M, Pankiewicz U, Sujka M, Kowalski R, Góral D, Kozłowicz K (2019b) Influence of pulsed electric field on accumulation of calcium in Lactobacillus rhamnosus B 442. J Microbiol Biotechnol. https://doi.org/10.4014/jmb.1908.08064 (in press)

Guderjan M, Guderjan M, Töpfl S, Angersbach A, Knorr D (2005) Impact of pulsed electric field treatment on the recovery and quality of plant oils. J Food Eng 67:281-287

Han Z, Zeng X, Zhang B, Yu S (2009) Effects of pulsed electric fields (PEF) treatment on the properties of corn starch. J Food Eng 93:318-323

Hemar B, Augustin M, Cheng L, Sanguansri P, Swiergon P, Wan J (2011) The effect of pulsed electric field processing on particle size and viscosity of milk and milk concentrates. Milchwissenschaft 66(2):126-128

Ho SY, Mittal GS, Cross JD (1997) Effects of high field electric pulses on the activity of selected enzymes. J Food Eng 31:69-84

Hong J, Zeng XA, Han Z, Brennan CS (2018) Effect of pulsed electric fields treatment on the nanostructure of esterified potato starch and their potential glycemic digestibility. Innov Food Sci Emerg Technol 45:438-446

Ignat A, Manzocco L, Brunton NP, Nicoli MC, Lyng JG (2015) The effect of pulsed electric field pre-treatments prior to deep-fat frying on quality aspects of potato fries. Innov Food Sci Emerg Technol 29:65-69

Indriani DW et al (2019) Effect of voltage and frequency in pasteurization pulsed electric field (PEF) continous system of pineapple (Ananas comosus [L.] Merr) Juice. IOP Conf Ser Mater Sci Eng 557:012046

Jaeger H, Janositz A, Knorr D (2010a) The Maillard reaction and its control during food processing. The potential of emerging technologies. Pathol Biol 58(3):207-213

Jaeger H, Meneses N, Moritz J, Knorr D (2010b) Model for the differentiation of temperature and electric field effects during thermal assisted PEF processing. J Food Eng 100:109-118

Jalté M, Lanoisellé J-L, Lebovka NI, Vorobiev E (2009) Freezing of potato tissue pre-treated by pulsed electric fields. LWT Food Sci Technol 42:576-580

Janositz A, Noack AK, Knorr D (2011) Pulsed electric fields and their impact on the diffusion characteristics of potato slices. LWT Food Sci Technol 44(9):1939-1945

Jin TZ, Yu Y, Gurtler JB (2017) Effects of pulsed electric field processing on microbial survival, quality change and nutritional characteristics of blueberries. LWT Food Sci Technol 77:517-524

Kotnik T, Miklavčič D (2006) Theoretical evaluation of voltage inducement on internal membranes of biological cells exposed to electric fields. Biophys J 90:480-491

Kotnik T, Pucihar G, Miklavcic D (2010) Induced transmembrane voltage and its correlation with electroporation-mediated molecular transport. J Membr Biol 236:3-13

Leach AR (2001) Molecular modelling: principles and applications, 8th edn. Prentice Hall, Upper Saddle River

Lebovka N, Praporscic I, Vorobiev E (2003) Enhanced expression of juice from soft vegetable tissues by pulsed electric fields: consolidation stages analysis. J Food Eng 59(2-3):309-317

Lebovka N, Praporscic I, Vorobiev E (2004) Effect of moderate thermal and pulsed electric field treatments on textural properties of carrots, potatoes and apple. Innov Food Sci Emerg Technol 5:9-16

Lebovka N, Shynkaryk N, Vorobiev E (2007) Pulsed electric field enhanced drying of potato tissue. J Food Eng 78:606-613
Lee PY, Lusk K, Mirosa M, Oey I (2015) Effect of information on Chinese consumers' perceptions and purchase intention for beverages processed by High Pressure Processing. Pulsed Electr Field Heat Treat Food Qual Prefer 40:16-23

Li Q, Wu QY, Jiang W, Qian JY, Zhang L, Wu M, Rao SQ, Wu CS (2019) Effect of pulsed electric field on structural properties and digestibility of starches with different crystalline type in solid state. Carbohydr Polym 207:362-370

Lin S, Liang R, Xue P, Zhang S, Liu Z, Dong X (2017) Antioxidant activity improvement of identified pine nut peptides by pulsed electric field (PEF) and the mechanism exploration. LWT Food Sci Technol 75:366-372

Liu Q, Huang Y, Ronghua Z, Tiange C, Cai Y (2016) Medical application of Spirulina platensis derived C-phycocyanin. J Evid Based Complement Altern Med 2016:1-15

Liu C, Grimi N, Lebovka N, Vorobiev E (2018a) Effects of preliminary treatment by pulsed electric fields and convective air-drying on characteristics of fried potato. Innov Food Sci Emerg Technol 47:454-460

Liu ZW, Zeng XA, Ngadi MO (2018b) Enhanced extraction of phenolic compounds from onion by pulsed electric field (PEF). J Food Process Preserv 42(5):13755

Lopez N, Pue'Rtolas E, Condo'n S, Raso J, Alvarez I (2009) Enhancement of the solid-liquid extraction of sucrose from sugar beet (Beta vulgaris) by pulsed electric fields. LWT Food Sci Technol 42:1674-1680

Luengo E, Álvarez I, Raso J (2013) Improving the pressing extraction of polyphenols of orange peel by pulsed electric fields. Innovative Food Sci Emerg Technol 17:79-84

MacDiarmid C, Milanick MA, Eide DJ (2002) Biochemical properties of vacuolar zinc transport systems of Saccharomyces cerevisiae. J Biol Chem 277:39187-39194

Magnuson B, Munro I, Abbot P, Baldwin N, Lopez-Garcia R, Ly K, McGirr L, Roberts A, Socolovsky S (2013) Review of the regulation and safety assessment of food substances in various countries and jurisdictions. Food Addit Contam A 30:1147-1220

Maherani B, Hossain F, Criado P, Ben-Fadhel Y, Salmieri S, Lacroix M (2016) World market development and consumer acceptance of irradiation technology. Foods 5(4):79

Marselle's-Fontanet A, Martin-Belloso O (2007) Optimization and validation of $\mathrm{PEF}$ processing conditions to inactivate oxidative enzymes of grape juice. J Food Eng 83:452-462

Martinez J, Luengo E, Saldana G, Alvarez I, Raso J (2017) C-phycocyanin extraction assisted by pulsed electric field from Artrosphira platensis. Food Res Int 99(3):1042-1047

Michalac S, Alvarez V, Ji T, Zhang QH (2003) Inactivation of selected microorganisms and properties of pulsed electric field processed milk. J Food Proces Preserv 27(2):137-151

Morales-De La Peña M, Salvia-Trujillo L, Garde-Cerdán T, RojasGraü M, Martín-Belloso O (2012) High intensity pulsed electric fields or thermal treatments effects on the amino acid profile of a fruit juice-soymilk beverage during refrigeration storage. Innov Food Sci Emerg Technol 16:47-53

National Advisory Committee on Microbiological Criteria for Foods (2004) Considerations for establishing safety-based consume-by date labels for refrigerated ready-to-eat foods. J Food Protect 68(8):1761-1775

Nielsen H, Sonne A, Grunert K, Banati D, Pollak-Toth A, Lakner Z, Olsen N, Zontar T, Peterman M (2009) Consumer perception of the use of high-pressure processing and pulsed electric field technologies in food production. Appetite 52:115-126

Odriozola-Serrano I, Soliva-Fortuny R, Martín-Belloso O (2008) Phenolic acids, flavonoids, vitamin $\mathrm{C}$ and antioxidant capacity of strawberry juices processed by high-intensity pulsed electric fields or heat treatments. Eur Food Res Technol 228:239 
Ostermeier R, Giersemehl P, Siemer C, Töpfl S, Jäger H (2018) Influence of pulsed electric field (PEF) pre-treatment on the convective drying kinetics of onions. J Food Eng 237:110-117

Palgan I, Muñoz A, Noci F, Whyte P, Morgan DJ, Cronin DA, Lyng JG (2012) Effectiveness of combined pulsed electric field (PEF) and manothermosonication (MTS) for the control of Listeria innocua in a smoothie type beverage. Food Control 25:621-625

Pankiewicz U, Jamroz J (2010) Effect of pulsed electric fields upon accumulation of magnesium in Saccharomyces cerevisiae. Eur Food Res Technol 231:663-668

Pankiewicz U, Jamroz J (2011) Effect of pulsed electric fields upon accumulation of zinc in Saccharomyces cerevisiae. J Microbiol Biotechnol 21: 646-651

Pankiewicz U, Jamroz J (2013) Application of pulsed electric field for enrichment of Saccharomyces cerevisiae cells with calcium ions. Ital J Food Sci 25(4):394-402

Pankiewicz U, Sujka M, Włodarczyk-Stasiak M, Mazurek A, Jamroz J (2014) Effect of pulse electric fields (PEF) on accumulation of magnesium and zinc ions in Saccharomyces cerevisiae cells. Food Chem 157:125-131

Pankiewicz U, Jamroz J, Sujka M, Kowalski R (2015) Visualization of calcium and zinc ions in Saccharomyces cerevisiae cells treated with PEFs (pulse electric fields) by laser confocal microscopy. Food Chem 188:16-23

Pankiewicz U, Sujka M, Kowalski R, Mazurek A, WłodarczykStasiak M, Jamroz J (2017) Effect of pulsed electric fields (PEF) on accumulation of selenium and zinc ions in Saccharomyces cerevisiae cells. Food Chem 221:1361-1370

Pankiewicz U, Góral M, Kozłowicz K, Góral D (2019) Novel method of zinc ions supplementing with fermented and unfermented ice cream with using PEF. Int J Food Sci Technol 54:2035-2044

Parniakov O, Bals O, Lebovka N, Vorobiev E (2016a) Pulsed electric field assisted vacuum freeze-drying of apple tissue. Innov Food Sci Emerg Technol 35:52-57

Parniakov O, Barba FJ, Grimi N, Lebovka N, Vorobiev E (2016b) Electro-biorefinery as a potential tool for valorization of mango and papaya by-products. In: Jarm T, Kramar P (eds) 1st World congress on electroporation and pulsed electric fields in biology, Medicine and Food \& Environmental Technologies. IFMBE Proceedings, vol 53. Springer, Singapore

Pataro G, Ferrentino G, Ricciardi C, Ferrari G (2010) Pulsed electric fields assisted microbial inactivation of $S$. cerevisiae cells by high pressure carbon dioxide. J Supercrit Fluid 54:120-128

Pataro G, Falcone M, Donsì G, Ferrari G (2014) Metal release from stainless steel electrodes of a PEF treatment chamber: effects of electrical parameters and food composition. Innov Food Sci Emerg Technol 21:58-65

Peiró S, Luengo E, Segovia F et al (2019) Improving polyphenol extraction from lemon residues by pulsed electric fields. Waste Biomass Valoris 10:889-897

Polokovsky M, Francois F, Sack M, Frey W, Muller G, Golberg A (2019) In silico food allergenic risk evaluation of proteins extracted from macroalgae Ulva sp. with pulsed electric fields. Food Chem 276:735-744

Puertolas E, Lopez N, Condon S, Alvarez I, Raso J (2010) Potential applications of PEF to improve red wine quality. Trends Food Sci Technol 21:247-255

Qin BL, Pothakamury UR, Vega-Mercado H, Martin-Belloso OM, Barbosa-Cánovas GV, Swanson BG (1995) Food pasteurization using high-intensity pulsed electric fields. Food Technol 12:55-60

Ravishankar S, Zhang H, Kempkes ML (2008) Pulsed electric fields. Food Sci Technol Int 14:429-432

Regulation (EU) 2015/2283 of the European Parliament and of the Council of 25 November 2015 on novel foods, amending Regulation (EU) No 1169/2011 of the European Parliament and of the Council and repealing Regulation (EC) No 258/97 of the European Parliament and of the Council and Commission Regulation (EC) No 1852/2001

Reineke K, Schottroff F, Meneses N, Knorr D (2015) Sterilization of liquid foods by pulsed electric fields-an innovative ultra-high temperature process. Front Microbiol 6:400

Riener J, Noci F, Cronin DA, Morgan DJ, Lyng JG (2009) Effect of high intensity pulsed electric fields on enzymes and vitamins in bovine raw milk. Int J Dairy Technol 62:1-6

Rodríguez-Roque MJ, de Ancos B, Sánchez-Moreno C, Cano MP, Elez-Martínez P, Martín-Belloso O (2015) Impact of food matrix and processing on the in vitro bioaccessibility of vitamin $\mathrm{C}$, phenolic compounds, and hydrophilic antioxidant activity from fruit juice-based beverages. J Funct Foods 14:33-43

Roodenburg B, Morren J, Berg HE, de Haan SWH (2005) Metal release in a stainless steel pulsed electric field (PEF) system. Part II. The treatment of orange juice; related to legislation and treatment chamber lifetime. Innov Food Sci Emerg Technol 6:337-345

Sadik MM, Li J, Shan JW, Shreiber DI, Lin H (2013) Quantification of propidium iodide delivery using millisecond electric pulses: experiments. Biochim Biophys Acta (BBA) Biomembr 1828:1322-1328

Salvia-Trujillo Morales-de, la Pena M, Rojas-Graü A, Martín-Belloso O (2011) Changes in water-soluble vitamins and antioxidant capacity of fruit juice-milk beverages as affected by highintensity pulsed electric fields (HIPEF) or heat during chilled storage. J Agric Food Chem 59(18):10034-10043

Segovia J, Luengo E, Corral-Perez J, Raso J, Almajano M (2014) Improvements in the aqueous extraction of polyphenols from borage (Borago officinalis L.) leaves by pulsed electric fields: pulsed electric fields (PEF) applications. Ind Crops Prod 65:390-396

Setlow P (1995) Mechanisms for the prevention of damage to DNA in spores of Bacillus species. Annu Rev Microbiol 49:29-54

Sharma P, Bremer P, Oey I, Everett DW (2014) Bacterial inactivation in whole milk using pulsed electric field processing. Int Dairy $\mathbf{J}$ 35:49-56

Sharma P, Oey I, Bremer P, Everett D (2017) Microbiological and enzymatic activity of bovine whole milk treated by pulsed electric fields. Int J Dairy Technol 71(1):10-19

Shayanfar S, Chauhan OP, Toepfl S, Heinz V (2013) The interaction of pulsed electric fields and texturizing-antifreezing agents in quality retention of defrosted potato strips. Int $\mathrm{J}$ Food Sci Technol 48:1289-1295

Shayanfar S, Chauhan OF, Toepfl S, Heinz V (2014) Pulsed electric field treatment prior to freezing carrot discs significantly maintains their initial quality parameters after thawing. Int $\mathbf{J}$ Food Sci Technol 49:1224-1230

Siemer C, Toepfl S, Heinz V (2014) Inactivation of Bacillus subtilis spores by pulsed electric fields (PEF) in combination with thermal energy-I. Influence of process- and product parameters. Food Control 39:163-171

Silve A, Ivorra A, Mir LM (2011) Detection of permeabilisation obtained by micropulses and nanopulses by means of bioimpedance of biological tissues. In: Proceedings of the 5th European conference on antennas and propagation (EUCAP), Rome, pp. 3164-3167

Silve A, Wegner L, Frey W (2017) Detection of effects of external electric pulses on properties of biological membrane with electrical and optical diagnostics. In: 11th European conference on antennas and propagation (EUCAP), Paris, pp 1354-1357

Soliva-Fortuny R, Balasa A, Knorr D, Martin-Belloso O (2009) Effects of pulsed electric fields on bioactive compounds in foods: a review. Trends Food Sci Technol 20:544-556 
Soliva-Fortuny R, Vendrell-Pacheco M, Martin-Belloso O, ElezMartinez P (2017) Effect of pulsed electric fields on the antioxidant potential of apples stored at different temperatures. Postharvest Biol Technol 132:195-201

Sonne AM, Grunert KG, Olsen NV, Granli BS, Szabo E, Banati D (2012) Consumer's perceptions of HPP and PEF food products. Br Food J 114:85-107

Syed QA, Ishaq A, Rahman UU, Aslam S, Shukat R (2017) Pulsed electric field technology in food preservation: a review. J Nutr Health Food Eng 6(5):168-172

Taufiqurrahmi N, Religia P, Mulyani G, Suryana D, Ichsan Tanjung FA, Arifin Y (2017) Phycocyanin extraction in Spirulina produced using agricultural waste. IOP Conf Ser Mater Sci Eng 206:012097

Teissié J, Tsong TY (1981) Electric field induced transient pores in phospholipid bilayer vesicles. Biochem 20(6):1548-1554

Telfser A, Gómez Galindo F (2019) Effect of reversible permeabilization in combination with different drying methods on the structure and sensorial quality of dried basil (Ocimum basilicum L.) leaves. LWT 99:148-155

Terefe NS, Buckow R, Versteeg C (2013) Quality related enzymes in plant based products: effects of novel food processing technologies. Part 2: pulsed electric field processing. Crit Rev Food Sci Nutr 55:1-15

Tieleman DP (2004) The molecular basis of electroporation. BMC Biochem 19:5-10

Tiwari B, O'Donell C, Cullen P (2009) New challenges in food science and technology: an industrial perspective. Trends Food Sci Technol 20:180-181

Toepfl S, Heinz V, Knorr D (2004) Optimization of pulsed electric field treatment for liquid food pasteurization. In: Proceedings of the 2nd European pulsed power symposium (EPPS) 2004. Shaker, Aachen, pp 68-72

Toepfl S, Heinz V, Knorr D (2006) In: Raso J, Heinz V (eds) Pulsed electric fields technology for the food industry. Fundamentals and applications. Springer, New York

Tsong TY (1996) Electrically stimulated membrane breakdown. In: Lynch PT, Davey MR (eds) Electrical manipulation of cells. Chapman \& Hall, New York, pp 15-36

Valič B, Golzio M, Pavlin M, Schatz A, Faurie C, Gabriel B, Teissié J, Rols MP, Miklavčič D (2003) Effect of electric field induced transmembrane potential on spheroidal cells: theory and experiment. Eur Biophys J 32:519
Vallverdú-Queralt A, Odriozola-Serrano I, Oms-Oliu G, LamuelaRaventos RM, Elez-Martínez P, Martín-Belloso O (2012) Changes in the polyphenol profile of tomato juices processed by pulsed electric fields. J Agric Food Chem 60:9667-9672

Velickova E, Tylewicz U, Dalla Rosa M, Winkelhausen E, Kuzmanova S, Romani S (2018) Effect of pulsed electric field coupled with vacuum infusion on quality parameters of frozen/ thawed strawberries. J Food Eng 233:57-64

Weaver JC (2003) Electroporation of biological membranes from multicellular to nanoscales. Dielectrics and electrical insulation. IEEE Trans Dielectr Electr Insul 10(5):754-768

Wiktor A, Schulz M, Voigt E, Witrowa-Rajchert D, Knorr D (2015) The effect of pulsed electric field treatment on immersion freezing, thawing and selected properties of apple tissue. J Food Eng 146:8-16

Wiktor A, Nowacka M, Dadan M, Rybak K, Lojkowski W, Chaduba T, Witrowa-Rajchert D (2016) The effect of pulsed electric field on drying kinetics, color, and microstructure of carrot. Dry Technol 34(11):1286-1296

Zeng F, Gao QY, Han Z, Zeng X, Yu S (2016) Structural properties and digestibility of pulsed electric field treated waxy rice starch. Food Chem 194:1313-1319

Zhang Q, Barbosa-Canovas GV, Swanson BG (1995) Engineering aspects of pulsed electric field pasteurization. J Food Eng 25:261-281

Zhang ZH, Han Z, Zeng XA, Wang MS (2017) The preparation of Feglycine complexes by a novel method (pulsed electric fields). Food Chem 219:468-476

Zhu N, Zhu Y, Yu N, Wei Y, Zhang J, Hou Y, Sun A (2019) Evaluation of microbial, physicochemical parameters and flavor of blueberry juice after microchip-pulsed electric field. Food Chem 274:146-155

Zimmerman U (1986) Electric breakdown, electropermeabiliziation and electrofision. Rev Physiol Biochem Pharmacol 105:196-256

Zulueta A, Esteve MJ, Frasquet I, Frígola A (2007) Fatty acid profile changes during orange juice-milk beverage processing by highpulsed electric field. Eur J Lipid Sci Technol 109:25-31

Publisher's Note Springer Nature remains neutral with regard to jurisdictional claims in published maps and institutional affiliations. 